\title{
Natural Hazard Resilient Communities and Land Use Planning: The Limitations of Planning Governance in Tropical Australia
}

\author{
Sharon Harwood ${ }^{1 *}$, Dean Carson ${ }^{2}$, Ed Wensing ${ }^{3}$ and Luke Jackson ${ }^{4}$ \\ ${ }^{1}$ School of Earth and Environmental Sciences, James Cook University, PO Box 6811, Cairns QLD 4870, Australia \\ ${ }^{2}$ Professor of Rural and Remote Research, Flinders University Rural Clinical School, PO Box 889, Nuriootpa SA 5355, Australia \\ ${ }^{3}$ National Centre for Indigenous Studies, The Australian National University, Canberra ACT 0200 \\ ${ }^{4}$ School of Earth and Environmental Sciences, James Cook University, PO Box 6811, Cairns QLD, 4870, Australia
}

\begin{abstract}
This paper examines how two Australian land use planning systems address the creation of hazard resilient communities in tropical areas. The application of substantive hazard knowledge and how this influences the associated procedures within the planning system is examined. The case studies of Darwin the capital of the Northern Territory, and the beachside suburb of Machans Beach within the Cairns Regional Council in far north Queensland are investigated. Both case study locations have experienced tropical cyclones since settlement and despite their hazard prone locations, both have intensified over their 120 year existence. Moreover, it is predicted that cyclones in tropical Australia will decrease in number, but increase in intensity. It would be rational to assume that industry, community and government would actively pursue planning strategies to negate the risks of natural hazards and the corresponding level of vulnerability to a hazard event. However, neither communities nor planning are driven by rational technical decision making processes. The paper concludes that the rhetoric for creating hazard resilient communities dominates national and state government policy, however this has minimal influence upon the legal framework that protects development rights. It would appear that the safe development paradox [1,2], is present in the Australian land use planning system, and that the focus of planning is on creating certainty of development rights and achieving efficiencies through urban settlement patterns, as opposed to creating hazard resilient communities.
\end{abstract}

Keywords: Hazard resilient communities; Darwin; Cairns; Storm surge; Cyclones

\section{Introduction}

Hazards borne of meteorological events are far more devastating to Australia than geological events such as earthquakes and landslides. According to Blong [3] from 1788 to 2003, 35 percent of total deaths from natural hazards in Australia were attributed to tropical cyclones, with a further 38 percent being attributed to flood events. Recent meteorological events in tropical north Queensland alone may have removed up to one and a half billion dollars from the local agricultural and tourism economy [4] and up to eight billion dollars in lost coal mining production [5]. In view of the extent of these losses, it would be rational to assume that industry, community and government would actively pursue planning strategies to mitigate the risk of natural hazards and the corresponding level of vulnerability to a hazard event. However, neither communities nor planning are driven by rational technical decision making processes.

It is the goal of the Australian federal government to create, facilitate or enhance a community's resilience [6] to natural disasters.

Hazards knowledge is (or is not) incorporated into statutory land use plans (also referred to as planning schemes) in two case study locations. The purpose of this examination is to ascertain the extent to which the 'safe development paradox' is prevalent within the two case study communities.

The 'safe development paradox' [1] describes how governments condone the use of hazardous areas for development provided steps are taken to make it safe for human occupation. These funded measures include engineering works such as flood levees, the application of building codes and setbacks for construction in hazard prone locations and disaster relief for affected home owners and businesses. These initiatives in turn influence how state and local governments respond to development in hazard prone locations.
State and local government entities recognise the presence of hazard induced risk through [1]:

- mitigation works (rock walls and flood levees);

- building practices including design to withstand strong winds, setback distances from rivers, oceans or dam walls; and

In the natural hazards literature, the term resilience is used to describe the extent to which an individual or a collective of individuals are able

- planning frameworks to guide the location of development away from hazard-prone areas.

Mitigation planning is often the responsibility of emergency services and has typically been limited to creating prepared communities through education on both pre- and post-event behaviour. In more recent times, the mitigation of natural hazards through land use planning has been recognised as playing an important role in creating a prepared and resilient community $[6,13,14]$. Land use planning frameworks can serve to proactively identify areas that are physically vulnerable and address the associated risks through the creation of

${ }^{*}$ Corresponding author: Sharon Harwood, School of Earth and Environmental Sciences, James Cook University, PO Box 6811, Cairns QLD 4870, Australia, Tel: 61-7-4042-1703; E-mail: sharon.harwood1@jcu.edu.au

Received June 26, 2014; Accepted July 31, 2014; Published October 14, 2014

Citation: Harwood S, Carson D, Wensing E, Jackson L (2014) Natural Hazard Resilient Communities and Land Use Planning: The Limitations of Planning Governance in Tropical Australia. J Geogr Nat Disast 4: 130. doi:10.4172/21670587.1000130

Copyright: (c) 2014 Harwood S, et al. This is an open-access article distributed under the terms of the Creative Commons Attribution License, which permits unrestricted use, distribution, and reproduction in any medium, provided the original author and source are credited. 
Citation: Harwood S, Carson D, Wensing E, Jackson L (2014) Natural Hazard Resilient Communities and Land Use Planning: The Limitations of Planning Governance in Tropical Australia. J Geogr Nat Disast 4: 130. doi:10.4172/2167-0587.1000130

Page 2 of 15

statutory development assessment frameworks that take these factors into consideration when making land use decisions and assessing development applications. This paper concentrates on the planning frameworks that are applied in two tropical cyclone-prone locations in northern Australia. The planning frameworks are assessed according to five key components, namely, planning legislation that includes the mandate for creating hazard-resilient communities, state planning policies that guide development in the hazard-prone location, local statutory plans (planning schemes), property disclosures and their relationship with emergency management systems.

The planning framework in the Northern Territory (NT) is reviewed in light of the reconstruction of its capital city, Darwin, following cyclone 'Tracy' in 1974. The paper discusses the adaptation, or as $\mathrm{Li}$ [8] describes it, the maladaptation to the planning knowledge gained from this experience and the limited impact that this knowledge has had on the planning provisions in both the Northern Territory and other tropical cyclone-prone locations. This is further supported through an investigation of a recently approved development application in the storm surge-prone suburb of Machans Beach within the city of Cairns in far north Queensland, to illustrate how land use planning may mitigate risk but does not consider community resilience.

To assist with understanding the interrelationships between natural disaster management and the land use planning systems in the Northern Territory and Queensland, we have included a timeline of significant natural disaster events and Australia's system of government from the 1870 to the present in Figure 1. In Figure 1, events relating to Cairns and the Queensland Government are shown above the timeline, and events relating to Darwin and the Northern Territory are shown below the timeline. Events relating to the Commonwealth are shown in italics.

\section{Background}

The term 'planning' is used in this paper to refer to the decisionmaking and plan-making processes that underpin change, or as Yiftachel [15] suggests, planning describes the publicly guided transformation of space. Planning is the process of managing change within communities and is a human activity undertaken by people for people. Planning, according to Chadwick [16], is a process of human forethought and the subsequent actions based upon that forethought that is focused upon the future. Planning is therefore future-oriented and simultaneously optimistic, because it assumes the ability of people within the system to control the forces that impact upon the future [16].

Planning systems include the legislation that governs the plans, the statutory planning schemes that regulate development, the development industry that lobbies for development, and the politicians, the community and planners who have different interpretations of what planning is about and how the benefits of development should be distributed. This invariably means that there are a series of competing realities and demands upon the system and what it should deliver. Traditionally however, the planning system has evolved to provide land use certainty to the development industry (particularly for housing and new urban development) and the community [17].

Planners working in the public sector increasingly rely on rational technical data inputs as 'evidence' to substantiate allocation decisions, such as where to permit development and the range of land uses including the suitable scale and intensity of these uses at a particular location. However, planning has adopted a risk framework to organise the evidence that underpins decisions regarding the allocation of land use rights to parcels of land that are inclined to be physically vulnerable to natural hazards such as a cyclones, storm surges, landslips, or

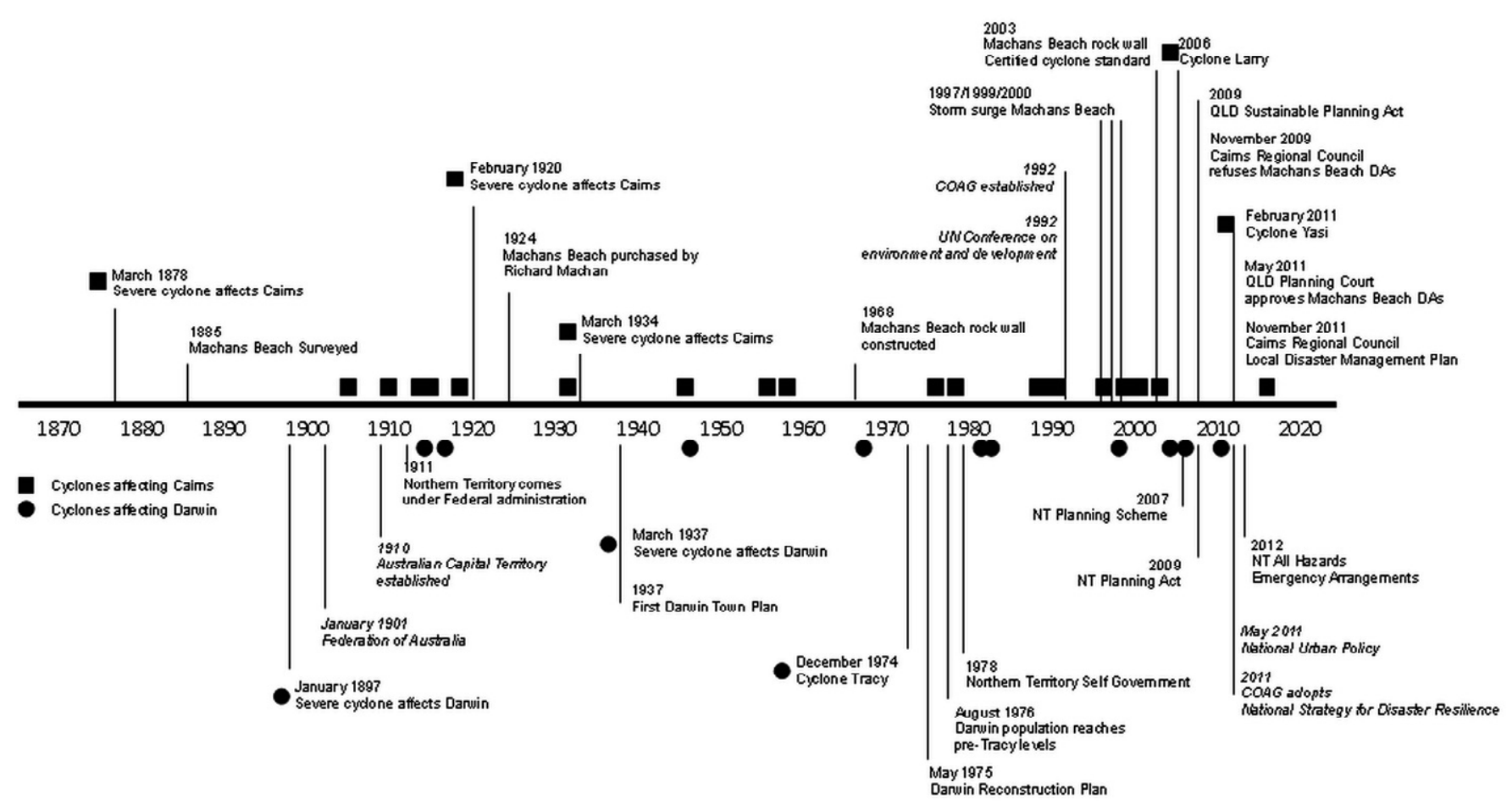

Figure 1: Timeline of significant natural disaster and related events 1870 to the 2014 relating to the case study locations of Cairns in far north Queensland and Darwin in the Northern Territory, Australia. 
bushfires [18]. Where risk is able to be mitigated through development conditions or engineering solutions, land use rights commensurate with the level of residual risk are subsequently attached to land. Development that is lawfully commenced and consistent with the land use plan cannot be rendered unlawful by the occurrence of any subsequent event such as a tropical cyclone. This means that land use rights cannot be retrospectively changed and existing land use plans cannot be adapted to reflect new knowledge. This protection against retrospectivity is how certainty in development rights is created, and in turn, how wealth is generated [19]. However, this inability to adapt to new knowledge has ramifications for creating hazard resilient communities.

\section{Hazard Resilient Community}

Hazard types vary and therefore the substantive knowledge applied to identify potential locations varies. A hazard prediction system is typically used to analyse the interaction between the hazard occurrence and land conditions [20]. A community that is located in an identified high hazard area, such as tropical areas that have a history of experiencing tropical cyclones and storm surges, will typically have a higher likelihood of experiencing an actual hazard event and is described as physically vulnerable [21]. Social vulnerability is a product of social inequalities and describes the susceptibility of social groups to the impacts of hazards and their ability to adequately recover from them [22]. Hazard related vulnerability describes the built, social, natural and economic environment that communities live within and how these in turn influence hazard susceptibility, response, recovery and overall resilience in the aftermath of a disaster.

The relationship between hazard, risk, vulnerability and resilience is complex and multi-dimensional. Generally, the literature suggests that there is an inverse relationship between vulnerability and resilience, whereby a highly vulnerable community possesses low levels of resilience [23]. Resilience has been studied from many different disciplines and as a consequence there is no one universally agreed definition of the term. According to Maguire and Cartwright [24], the term has been applied in engineering to refer to the ability of a material to return to its pre-existing state after being subject to stress. The term has also been extensively researched in the discipline of psychology to describe how individuals respond to trauma [25]. More recently, the term has been applied in community psychology to describe how a group of individuals collectively respond to a shared change in circumstances, such as drought [26], type of development [27-29] or climate induced environmental change [30,31]. The term resilience has been defined by Bonanno [6] as the amount and/or type of disturbance the affected community can absorb and still remain within or function as a minimum in the same state after experiencing stress.

The term 'social vulnerability' $[21,32,33]$ is used to refer to subpopulations of communities located in physically vulnerable areas that are affected by social factors that shape their susceptibility to harm and govern their ability to respond.

Populations that are known to be socially vulnerable are characterised by [34-36] age, low health, gender, marital status, race, income and housing conditions. Land use planning can identify places that are physically vulnerable to hazards. However, the relationship between land use planning, hazards and social vulnerability is far more complex and poorly understood.

According to the hazards literature, a resilient community has the ability to maintain its basic functions before, during and after an event and is able to return to its original state after an event has occurred, see for instance [24, 37-39]. The ability of the community to adapt to the change in a positive and effective way helps to determine the level of resilience [27]. The key components of resilience were described by Norris et al [40] as being a capacity to successfully adapt in the face of disturbance, stress or adversity. They undertook a content analysis of the definition of resilience in the literature and determined that there were six interpretations of resilience within twenty one research papers. These were described broadly as physical, ecological system, social, city, community and individual. Each of the twenty one definitions analysed, shared two common features, namely: a stress stimuli and a collective response to the stimuli. It is the response to the stimuli that is the focus of resilience. The entity is described as resilient, if after experiencing the stress stimuli, they are able to survive in a minimal state as they did before the stress. However, none of the literature seems to have considered the notion that a community may not be resilient if their settlement is destroyed and residents are either killed or do not return after the disaster strikes. The disintegration of a community is also an important component of resilience, as it describes a community that is incapable of returning to its original state after the disaster event. Disintegration in this sense, is the opposite state to resilient as it suggests that the integrity of the community is incapable of adapting after the hazard event and the response may include relocation, as opposed to rebuild or resettle in the same location.

Recent research [37-39] identifies there are three forms of resilience associated with natural hazards:

1. Stability resilience is the most recognised type of resilience as it refers to the ability of a community to return to its pre- disaster state. This type of resilience is measured by the amount of disturbance a system can tolerate before it shifts to an alternative state. This definition relies on the use of a threshold to determine the level of resilience. A resilient community displays a high change threshold and possesses the capacity to absorb and tolerate stress before the threshold is breached.

2. Resilience as recovery is described as the ability of a community to bounce back from a stressor or force and return to its original state. Resilience in this instance is measured on the time taken for a community to return to its original state.

3. Resilience as transformation is the capacity of a community to respond to a change adaptively. Unlike the other forms of resilience where the community returns to its pre-existing state, transformative resilience sees a more suitable and sustainable approach to the current environment. This form of resilience is concerned with the concepts of renewal, regeneration and reorganisation [38].

These definitions of resilience can be viewed as a continuum from disintegration to transformation to describe the capacity of a community to respond to a natural hazard (Figure 2).

Disintegration has social and physical components that are yet to be discussed in the literature to determine what level of disturbance precipitates the decision to rebuild or relocate. For instance, Darwin's population numbers had recovered to pre-cyclone levels within two years after cyclone Tracy in 1974. However, the demographic composition of the population changed dramatically. About 60 percent of the Darwin population who left after cyclone Tracy did not return [41]. This has serious implications for the functioning of social networks within a community and the level or type of resilience that may be achieved subsequent to a disaster. The pre-cyclone Darwin community will not function as it did before the cyclone because it retained only 40 percent of its original population. Land use planning plays an integral role in the creation of hazard resilient communities 
Citation: Harwood S, Carson D, Wensing E, Jackson L (2014) Natural Hazard Resilient Communities and Land Use Planning: The Limitations of Planning Governance in Tropical Australia. J Geogr Nat Disast 4: 130. doi:10.4172/2167-0587.1000130

Page 4 of 15

Disintegration Stability Recovery Transformation

Figure 2: Continuum of Hazard Resilience.

because the frameworks that underpin decision making can influence where settlements and future communities can be established.

To understand the relationship between land use planning and hazard resilient communities in tropical Australia requires an understanding of one of the most devastating disasters in Australian history, 'cyclone Tracy' and the responses and policy initiatives that ensued.

\section{Cyclone Tracy and Planning in Tropical Australia}

On Christmas Eve in December 1974, cyclone Tracy destroyed Darwin, and claimed 65 lives. Of the 8,000 houses in Darwin, approximately 5,000 were destroyed or damaged beyond repair and only 500 remained intact and continuously habitable [42]. The suburb of Wagaman experienced extensive damage from cyclone Tracy (Figure 3 ). With this devastation came the loss of critical infrastructure services such as sewerage, drinking water, communications and electricity. The solution to the immediate problem was a mass evacuation. Within a matter of hours of Tracy's landfall, the most extensive evacuation in Australian history commenced. About 25,658 residents were airlifted more than $3,000 \mathrm{~km}$ away, 11,000 self-evacuated (departures in private vehicles) and 10,500 remained to facilitate the clean-up [43].

It should be noted that Darwin has a long and contentious history of development controls, aside from those related to land within the stormsurge zones. Since the first town plan was introduced in 1937, there has been conflict either between the Commonwealth Government (as administrators of the Northern Territory or the Defence Department), the city/municipal council or the residents. This conflict was particularly heightened subsequent to cyclone Tracy when the Commonwealth Government established the Darwin Reconstruction Commission (DRC) to oversee its planning and reconstruction. The DRC viewed the reconstruction of Darwin as an opportunity to redress the ills of the past, to redesign the town and create a new plan. This plan was delivered in May 1975 amid controversy and criticisms from all sectors of the community and government. However, the most contentious issue was related to development (or more aptly the prohibition of development) on the 1000 lots (or 20 percent of the total privately owned lot stock) that fell below the storm-surge line. The conflict over these and other planning controls along with lack of Commonwealth funding to pay for the compulsory acquisition of these storm surgeaffected blocks did little to obstruct the pre-Tracy population resettling on the same block [44]. The planners had expected a slow repatriation, but by June 1975 there were 33,000 people (70 percent of the size of the pre-cyclone population) back in Darwin. This meant that the plan was no longer able to be adopted in its original form and this forced the DRC to turn its focus from planning to reconstruction. Moreover, a change in DRC leadership due to a lack of public confidence, saw, amongst other things, the recognition of pre-cyclone land use rights and a more flexible planning scheme containing land use categories that were far broader than those of the pre-cyclone scheme [44].

Despite assertions by Li [8] that the land use planning system in the NT has in essence malfunctioned since Tracy, Li [8] maintains that it failed to recognise the role the community plays in making decisions about land uses. While it may appear irrational and therefore a 'maladaptive' response to permit the resettlement of a storm-surge zone, it is the value-laden nature of the planning system that responded to the demands of the community subsequent to Tracy, in combination with a range of failed policy initiatives that gave land owners no choice but to resettle within the storm surge zones of Darwin. The failed compulsory acquisition policy initiatives of the Commonwealth had such a devastating effect on the psyche of the residents that they resulted in a more relaxed regulatory environment that would not usurp their future rights to live and use the land as they chose [44]. In essence, the land use planning system was a tool for expressing these social values and very little change in the development provisions since 1978 has occurred, including the ability to intensify development within these zones.

This article describes two adaptive responses to knowledge about natural hazards in the current land use planning frameworks in tropical Australia to describe the relationship between hazard resilience and land use planning since cyclone Tracy. The legislative and policy arrangements in Australia, like most other federated nations in the world, are complex due to the structure of our federation established and enshrined in the Australian Constitution. The following section explains the complexities of our system of government to enable a more in-depth understanding of the issues involved in creating hazard resilient communities through land use planning.

\section{Land Use Planning and Disaster Resilient Communities in Australia}

Under the Constitution, Australia's federal system of government has resulted in a tripartite hierarchy of political power consisting of a federal (national) government with limited powers, 8 state and territory governments, and 560 local governments. The six colonial States came together in 1901 to form the Australian federation, the Commonwealth of Australia. As a consequence of Section 125 of the Constitution, and almost a decade after federation in 1910, the state of New South Wales (NSW) surrendered a portion of NSW to become the Australian Capital Territory for the Seat of Government for the Commonwealth. In 1989, the Commonwealth granted the Australian Capital Territory responsible government, with a Legislative Assembly headed by a Chief Minister. In January 1911, a decade after federation, the Northern Territory (NT) was separated from South Australia and transferred to the Commonwealth and an Administrator was appointed by the Governor-General to administer the NT on behalf of the Commonwealth. In 1978, the Commonwealth granted the

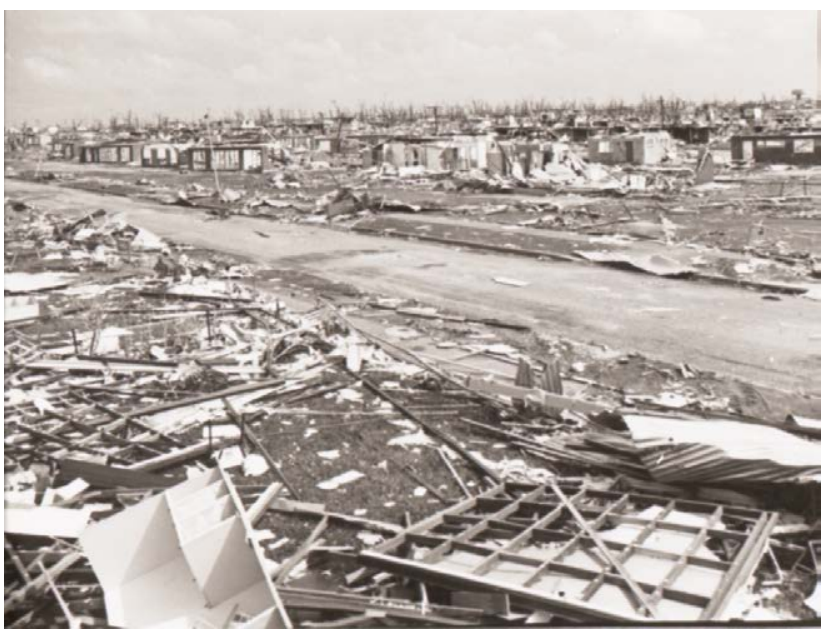

Figure 3: The suburb of Wagaman in Darwin after cyclone Tracy. 
Territory responsible government, with a Legislative Assembly headed by a Chief Minister.

To overcome some of the structural impediments to national policy development, the Commonwealth, the six States and the two self-governing Territories agreed to the establishment of the Council of Australian Governments (COAG). COAG's primary role is to facilitate policy reforms that are of national significance and that require the co-ordination of all levels of government. In 2011, COAG underwent a structural reform and reduced the overall number and types of Ministerial Councils operating under its umbrella [45]. COAG decided to establish a system of three types of ministerial councils, comprising ongoing standing councils to address issues of national significance; select councils that are reform-focused and time-limited; and legislative and governance fora for overseeing responsibilities set out in particular legislation, intergovernmental agreements and treaties outside the scope of standing councils. The nature and responsibilities of some of the Standing Councils and other fora relating to national policy development for emergency management, disaster resilience and land use planning are discussed below. COAG has also established the COAG Reform Council as part of the arrangements for federal financial relations to assist COAG to drive its reform agenda. Independent of individual governments, the COAG Reform Council reports directly to COAG on reforms of national significance that require cooperative action by Australian governments. The COAG Reform Council's mission is to assist COAG in strengthening the performance and public accountability of governments, and it does this by monitoring the performance of the various National Partnerships and Agreements that COAG enters into.

The membership of COAG comprises the Prime Minister, the six State Premiers, the two Territory Chief Ministers and the President of the Australian Local Government Association representing the third tier of government in Australia, local government. Local Government has no independent constitutional status in Australia, it derives most of its powers solely from state legislation, via Local Government Acts in each state and the NT. Other legislation confers additional powers on local government, such as for planning and the regulation of development. As Williams and Maginn [46] observe, within this legislative framework, local governments can exercise a large degree of autonomy over some services, while also being an agency for the State or Federal Governments on other matters.

Figure 4 shows the responsibilities for emergency management, land use planning, local government and disaster resilience in the Australia's federal system of government (as it was in June 2013).

Section 51 of the Australian Constitution contains the powers conferred on the Federal Government by the States. Significantly, the Federal Government does not have any specific powers for emergency management, disaster resilience or land use planning and regulation of development because the States and Territories retained responsibility for these matters.

Primary responsibility for the protection of life, property and the environment rests with the States and Territories and this includes the provision of police, fire, ambulance services and emergency service organisations, State Emergency Services or SES, comprising of staff and volunteers who provide a disaster response capability within each jurisdiction. Managing emergencies is also the responsibility of State and Territory Governments with local governments playing a significant role. State and Territory Governments have arrangements with each other to share resources when necessary and, in particularly major disasters or adverse events, a State or Territory Government may seek federal assistance [47].

At the national level, the Ministerial Council on Police and Emergency Management (SCPEM) is a Standing Council of COAG with its membership comprising ministers responsible for Police and Emergency Management from the federal, state and territory governments and from New Zealand and an Australian Local Government Association (ALGA) representative. In relation to emergency management, the Ministerial Council promotes a coordinated national response to emergency management issues, provides a framework for cooperation and shared strategic directions for Australia and New Zealand, and encourages and shares best practice across the jurisdictions. The Ministerial Council is also responsible for providing national leadership on emergency management (all hazards) and disaster resilience, including national policies and priorities, and the consideration of recommendations of national interest arising from commissions of inquiry into recent natural disasters. The Federal Government through the Attorney-General's Department (AGD) provides the secretariat for the SCPEM and supports the States and Territories by providing a comprehensive approach to emergency management, assisting them with developing their capacity for dealing with emergencies and disasters, and for providing physical assistance to requesting States or Territories when they cannot reasonably cope during an emergency.

In 2009, COAG [48] agreed to adopt a whole-of-nation resiliencebased approach to disaster management, recognising that a national, coordinated and cooperative effort is needed to enhance Australia's capacity to withstand and recover from emergencies and natural disasters. The SCPEM therefore prepared a National Strategy for Disaster Resilience (NSDR) which was adopted by COAG in 2011 [45] The Strategy provides high-level guidance on disaster management to all levels of government, business and community leaders and the not-for-profit sector. While it focuses on priority areas to build disaster resilient communities across Australia, it also recognises that disaster resilience is a shared responsibility for individuals, households, businesses and communities, as well as for governments. The Strategy is also seen as a first step in delivering long term sustained behavioural change and enduring partnerships [47]. To this end, the Strategy includes a number of suggested priority outcomes in relation to reducing risks in the built environment through land use planning, development control and building regulations [47], including:

1. All levels of decision making in land use planning and building control systems take into account information on risks to the social, built, economic and natural environments.

2. Information on the likelihood of damage from hazards is actively shared, and tools are available to support understanding of potential consequences and costs.

1. Building standards and their implementation are regularly reviewed to ensure they are appropriate for the risk environment.

2. Development decisions take account of both private and public risks.

3. Natural hazard management principles are included in tertiary and vocational training and education curricula for relevant professional and building industry sectors.

4. Settlements, businesses and infrastructure are, as far as is practicable, not exposed to unreasonable risks from hazards or 


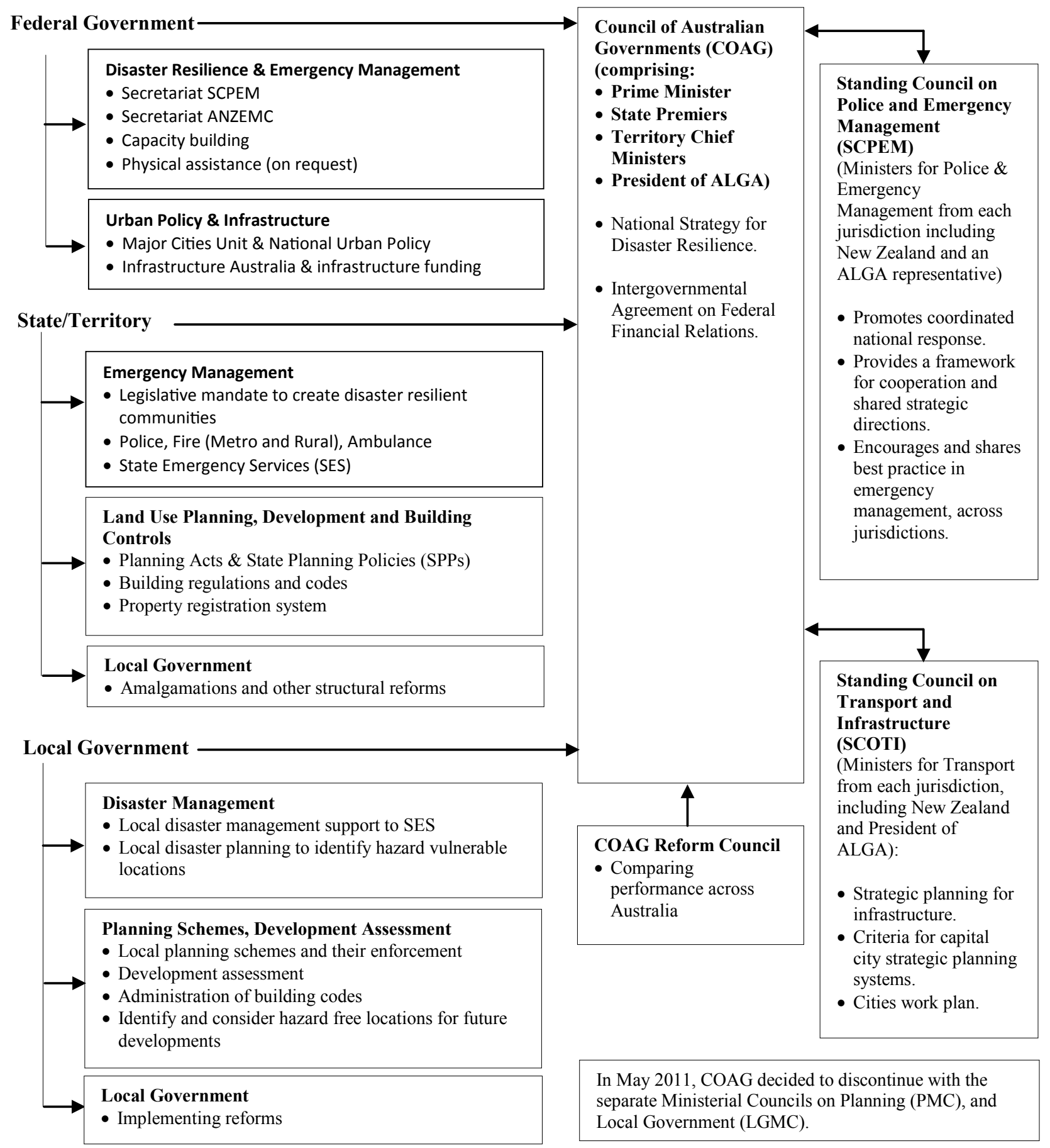

Figure 4: Responsibilities for emergency management, land use planning and disaster resilience in the Australian federal system.

have implemented suitable arrangements, which may include hardening infrastructure or taking up adequate insurance, to protect life and property from known hazards.

5. Following a disaster, the appropriateness of rebuilding in the same location, or rebuilding to a more resilient standard to reduce future risks, is adequately considered by authorities and individuals.

For many years there were separate Ministerial Councils for Local
Government and Planning that provided forums for coordination on urban affairs, land use planning and other local government matters, but in May 2011 COAG decided not to continue with those Councils. Nevertheless, COAG agreed in 2009 to a review of capital city planning and adopted a set of nine national criteria for capital city strategic planning systems [48] and in 2012 agreed that further work on cities would be taken forward by the COAG Standing Council on Transport and Infrastructure [49]. The primary responsibility of SCOTI is to ensure Australian cities are globally competitive, productive, 
sustainable, liveable and socially inclusive and are well placed to meet future challenges and growth [50].

The national criteria for capital city strategic planning was reviewed by the COAG Reform Council in 2012 to determine the extent to which they improved integration and consistency in planning and delivery across relevant parts of government, especially transport, economic development and land use [51]. The review concluded that none of the capital city strategic planning systems were found to be wholly consistent with the national criteria [50]. Moreover, there was no consideration given to hazard mitigation within the review nor were there any recommendations to address natural hazards within the land use planning frameworks. There are no linkages or references to the seven priority suggestions in the NSDR mentioned above to ensure they are reflected in the strategic planning frameworks for our capital cities.

In May 2011, the federal Minister for Infrastructure and Transport released the Government's National Urban Policy [52], setting in place the Australian Government's objectives and directions for our major cities.

What is noteworthy about these developments in relation to land use planning is that none of these initiatives extend to improving the land use planning systems to consider disaster resilience in towns and settlements across Australia, let alone across tropical Australia where the impacts of climate change are likely to be greater.

What this analysis demonstrates is that land use planning is not evolving in response to improvements in knowledge and information about the likely impacts arising from natural hazards and the impacts of climate changes. While there has been some shift in emphasis from merely facilitating development to considering the impacts of land use and development on ecological processes since the United Nations Conference on Environment and Development (UNCED) took place in Rio de Janeiro, Brazil in 1992, land use planning systems are yet to fully embrace their role in mitigating the risks to loss of life, property damage and destruction of vital infrastructure arising from natural hazards and climate change.

The NSDR makes some important suggestions with respect to reducing risks in the built environment, but there is still room for improvement in integrating these considerations into land use planning processes. The lack of integration between the set tasks of the SCPEM and SCOTI discussed above, shows the lack of integration at the national level. The two case studies documented below, highlight the importance of integrating data sets that emergency management agencies collect and apply in their hazard management activities, into land use planning frameworks and processes to improve the level of hazard resilience in new and established communities.

\section{Case Study Methods}

The risks and consequences from natural hazards vary depending on the location, the demographic profile, the physical characteristics of the community and the type and scale of development. Land use planning when combined with building standards can mitigate the likelihood of loss of life, as well as damage to and/or the destruction of property and infrastructure [6].

Strategic and statutory land use planning that takes the risks associated with natural hazards into account is critical therefore to the creation of safe, resilient and sustainable communities. The location of current settlements or their planned expansion to accommodate population growth through new development can either create or exacerbate exposure to natural hazards. Land use planning can be used to reduce the level of risk in areas where risk profiles were not well understood at an earlier point in time and our level of understanding has since improved.

To ascertain how well land use planning takes account of natural hazards and produces disaster resilient communities, we applied a 'comparative study in public policy and administration' approach [53] by examining the relationship between the problem (hazard vulnerability and disaster resilience) and the solutions (hazard mitigation) through land use planning. Our case study locations (discussed below) are in two different jurisdictions in Australia. While each jurisdiction has the power to create its own separate procedures specific to its history and circumstances, we assessed five common elements within each of these systems for measures that require or encourage natural hazard resilience, as follows:

1. Planning Legislation - Does the object of the legislation require plans or the planning process to create natural hazard resilient communities? Does strategic planning (for the expansions of current communities or the location of future communities) or the preparation of statutory planning instruments consider the vulnerability of communities to natural hazards and require the inclusion of abatement or mitigation measures in subordinate instruments?

2. State Planning Policies (instruments that protect matters of importance or significance to the state or territory) - Are there state planning policies specific to hazard mitigation in place within the jurisdiction and if so, are they reflected in other state or territory planning instruments and are local government planning schemes required to take them into consideration?

3. Planning Schemes and Development Assessment - To what extent are statutory planning schemes required to consider natural hazards risks and either prohibit or limit development in identified hazard locations? Do development assessment processes assess the natural hazard risks at the individual site or project level?

4. Property Disclosure Requirements - Does the property register system include a requirement to disclose information about the location of the land in relation to hazards and in this case flood maps and storm surge maps?

5. Emergency Management Systems - What data does the emergency management system collect and collate to identify and mitigate the risk of natural disasters (in this case cyclones and storm surge), and to what extent is this data made available to state/territory and local government agencies with responsibility for land use planning and development assessment?

The first four elements comprise the land use planning frameworks which are broadly similar in each jurisdiction. The final element was particularly important because we wanted to ascertain the extent to which data collected by emergency management agencies was being used in land use planning processes to develop disaster resilient communities.

\section{Case Study Selection}

The two case study locations of Darwin and Machans Beach in Cairns have experienced numerous tropical cyclones in the past 50 years (Figures 1 and 5).

Darwin, the capital city of the Northern Territory has experienced eleven tropical cyclones within a $50 \mathrm{~km}$ radius and 40 within a $200 \mathrm{~km}$ 
Citation: Harwood S, Carson D, Wensing E, Jackson L (2014) Natural Hazard Resilient Communities and Land Use Planning: The Limitations of Planning Governance in Tropical Australia. J Geogr Nat Disast 4: 130. doi:10.4172/2167-0587.1000130

Page 8 of 15

radius of the city centre in the past 50 years [54] (these are represented by the solid round dots below the line in Figure 1). Darwin has experienced three catastrophic cyclones in its history of European settlement, the first of which was in 1897, the second in 1937 and cyclone 'Tracy' in 1974. Cyclone Tracy has had a profound impact upon the psyche of tropical Australia, and far greater attention has been paid to both building codes and the social aspects of development planning [54].

Machans Beach, a delta suburb [18] within the jurisdiction of the Cairns Regional Council fronts onto the Coral Sea and is located between three rivers. This suburb has experienced 10 tropical cyclones within a $50 \mathrm{~km}$ radius and 38 within a $200 \mathrm{~km}$ radius in the past 50 years (These are represented by the solid squares above the line in Figure 1). The settlement of Cairns has been severely affected by three cyclones in its history, one in 1878 , which saw the re-siting of the city, another in 1920 that destroyed many buildings and produced a storm tide that inundated the town to a level of about one metre above high tide and again in 1934 that caused substantial building damage in Cairns and at least 75 people perished at sea in the immediate area.

Both of these tropical locations experience similar frequencies of cyclones. However, the purpose of examining the planning frameworks and emergency management systems associated with each of the case studies is to ascertain how the planning framework currently applies hazard knowledge to create disaster resilient communities.

\section{Case study 1: Darwin, Northern Territory (NT)}

In 2011 Darwin had a resident population of about 129,000 people [54]. Development for the entire NT is controlled through the NT Planning Scheme (2007) and is subordinate to the territory-wide planning legislation Northern Territory of Australia Planning Act (2009) - the NT Act. The objects of this Act are 'to plan for, and provide a framework of controls for, the orderly use and development of land' [56]. The Act also states that the objects are to be achieved by:

(a) strategic planning of land use and development and for the sustainable use of resources; (b) strategic planning of transport corridors and other public infrastructure;

(c) effective controls and guidelines for the appropriate use of land, having regard to its capabilities and limitations;

(d) control of development to provide protection of the natural environment, including by sustainable use of land and water resources;

(e) minimising adverse impacts of development on existing amenity and, wherever possible, ensuring that amenity is enhanced as a result of development;

(f) ensuring, as far as possible, that planning reflects the wishes and needs of the community through appropriate public consultation and input in both the formulation and implementation of planning schemes; and

(g) fair and open decision making and appeals processes [56].

The objects of the NT Act do not specifically mention hazard mitigation. Rather, the focus is on the creation of a system of land use and development control.

NT Planning Scheme [56] specifically protects existing lawful uses (and associated rights) of the land prior and subsequent to a planning scheme coming into effect. The NT Planning Scheme does however, mention risk mitigation specifically as this relates to meteorological hazards, and requires the consideration of flood and storm surge levels associated with floods and cyclones to minimise risk to life and property [56]

The NT Planning Scheme [56] applies storm-surge maps to delineate primary and secondary storm-surge zones that may be affected. To mitigate risk to person and property the planning scheme requires all development within the primary storm-surge zone to gain the approval of the Development Consent Authority (DCA) and grants certain concessions to development within the secondary zones. Where development does not trigger the provisions within the NT Planning Scheme, the building code requires compliance with structural safety standards.

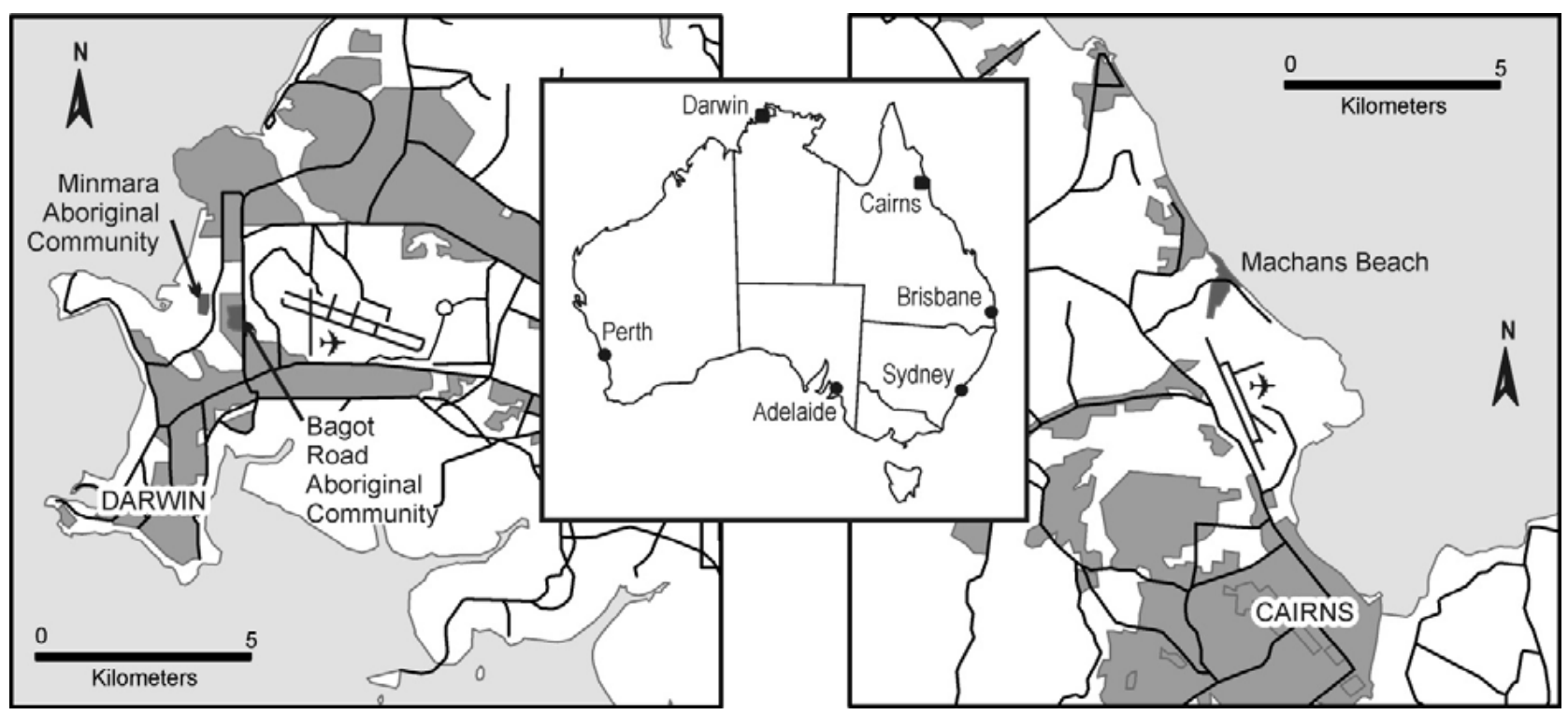

Figure 5: Darwin and Cairns. 
The assessment process within the NT Planning Scheme is triggered for specific land uses. For instance, in the zone described as Community Living (which is the designation assigned to the land that the Bagot Road and Minmarra Aboriginal communities are located), it is permitted to create extra dwellings, shops, medical centres, group homes and community centres without further planning consent. Should a proponent seek approval for an office, bed and breakfast, horticultural development or a promotional sign, they must gain approval from the DCA. When the permitted land uses contained within the definition of Community Living are examined in combination with the demographic characteristics of Aboriginal communities, it becomes particularly evident that the facilities required for community resilience (medical centres, community centres and shops) are at greatest risk to the impacts of storm surges. However, offices, bed and breakfasts, horticultural developments and promotional signs that have much less to do with resilience and recovery, require greater planning control.

There are no Territory-level planning policies in the Northern Territory land use planning framework, nor are there any specific policies regarding the location of development within the identified hazard locations. All development including location of just about everything is controlled via the planning scheme. There are no higher order statutory mechanisms that can override these or policies that require the consideration of factors that would contribute to a community's hazard resilience in the event of natural disasters. Moreover, there are no statutory provisions in the NT that require natural hazard information to be noted on land titles.

The Northern Territory Government's hazard management policy 'All Hazards Emergency Management Arrangements' [57] specifically identifies the role that land use planning plays in creating prepared and resilient communities. The NT Counter Disaster Council has audited the hazards and risks that might affect the Territory and have allocated response responsibilities based on the extent of the disaster experienced. While land use planning is identified within the Emergency Management Arrangements (Figure 6) as playing a role in the creating prepared communities, these arrangements focus solely upon the organisation of government agencies in the event of a disaster.

Data published by the NT Emergency Services to identify the relevant storm-surge zones is available and is used within the NT Planning Scheme. Yet, despite the availability of this data and associated mapping, development continues to intensify in storm-surge zones. The NT Planning Scheme does not prohibit development within stormsurge areas for two reasons. Firstly, there is no higher order policy or legislation that enables this prohibition; and secondly, the planning framework is based on risk mitigation and contains provisions to reduce risk through measures such as declaring a minimum floorlevel of habitable rooms in primary and secondary storm-surge zones (typically $300 \mathrm{~mm}$ above the identified site flood-level).

In addition there are a series of Local Counter Disaster Management Plans that each local area has prepared and are required to follow in the event of a disaster. These plans are created to prevent disasters and are used to assess threats most likely to affect the community and include a general description of the community including its population, major infrastructure and topography. These plans, including the assessment process and the outcomes of the risk assessment, are not considered in the preparation of the NT Planning Scheme pursuant to the NT Planning Act 2009, nor are they referred to by the Development Consent Authority when undertaking development assessment to ensure that planning contributes to creating hazard-resilient communities. In sum,

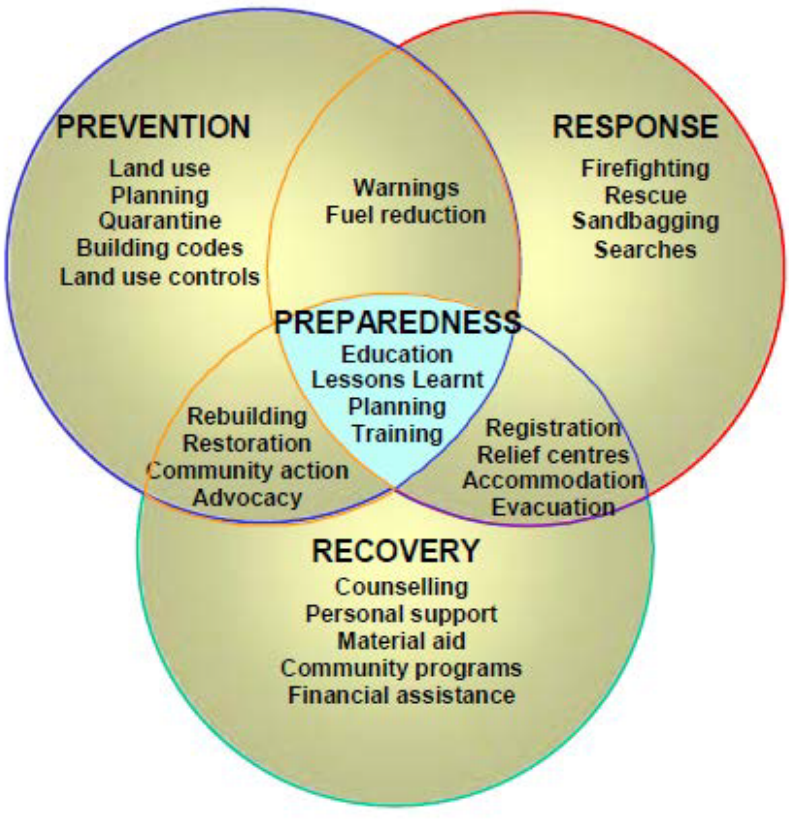

Figure 6: Land Use Planning within the NT All Hazards Emergency Management Arrangements [56:13].

the land use planning framework functions without using the data created and used by the Emergency Services in the Northern Territory.

\section{Case study 2: Machans Beach, Queensland}

Machans Beach is located within the Barron River Delta, surrounded by three river networks, (Barr Creek, Redden Creek and the Barron River) and has a $2.5 \mathrm{~km}$ shoreline along the Coral Sea. During moderate to high rainfall events the rivers often breach the mainland causing flooding to properties located along the delta. The resident population is about 941 people [58], was first surveyed in 1885 (seven years after the first recorded devastating cyclone) and was later purchased by Richard Machan in 1924 (four years after Cairns' worst cyclone). The shoreline along Machans has been subject to extensive erosion since development began in the early 1930s. After experiencing extensive erosion (Figure 7) and threat to property for more than 40 years, the residents called for a community-based and partially councilfunded initiative to build a rock wall in 1968. The purpose of the rock wall was to reduce erosion and buffer tidal events. The position of the shoreline highlights the impact of tides and storm activities upon the Machans Beach foreshore. In 1968 the rock wall was constructed and this has protected the settlement from further shoreline retreat (Figure $8)$.

Despite the presence of this rock wall, the Machans Beach community continues to report concerns about the lack of maintenance undertaken by the local government [59]. The community maintains this wall through its own efforts [58] and has expressed serious concerns over the structural integrity and capacity of the wall to withstand a significant tropical cyclone and storm surge. Cyclones, identified the southern of the two lots subject to the court proceedings, to be within the zone of highest storm-surge flood risk. The northern lot is not located in a storm-surge flood zone and was again un-coloured (i.e. unclassified). In sum, this case highlights a disconnect between the hazard data applied by the emergency management agencies and the omission of this data in the development of local planning schemes 


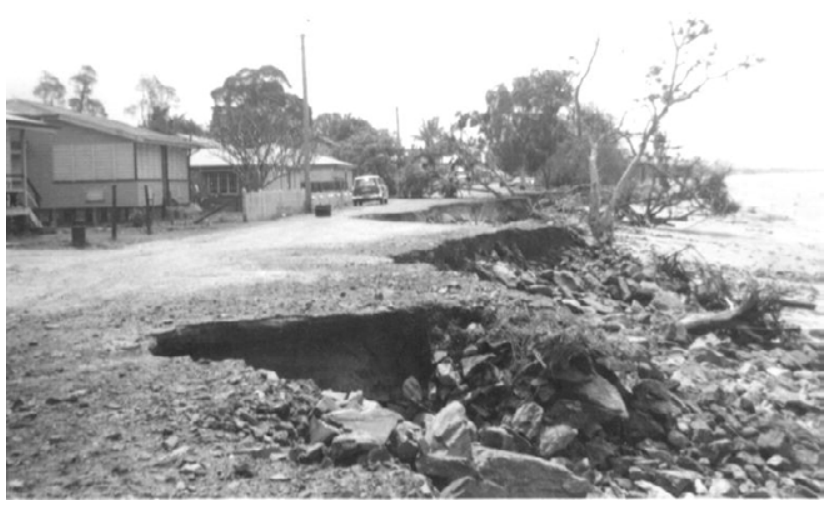

Figure 7: Machans Beach 1966 after king tide (photo Courtesy of Cairns Historical Society).

to enhance the community's resilience by ensuring development is located outside high-risk zones.

\section{Discussion}

This analysis examined the land use planning and emergency management systems in two jurisdictions within tropical Australia to determine the extent to which natural hazards are considered, hazard resilient communities are created and the failure of the 'safedevelopment paradox' resulting from disconnection between the two systems. A summary of our comparisons between the two jurisdictions is shown in Table 1.

Neither of the two jurisdictions (NT and Qld) use their land use planning systems effectively to create hazard resilient communities and neither of their property registrations systems make the disclosure of hazard data about properties mandatory. Queensland has a state planning policy for mitigating the adverse impacts of natural hazards but it only deals with floods, bushfires and landslides, and which has been under review for two years despite the fact that 95 percent of the State of Queensland was declared a disaster zone in early 2011. The SPP does not deal with the adverse impacts of cyclones, sea level rise or high tidal surges. The NT planning system does not include any provisions for Territory planning policies. The focus of the land use planning systems in both jurisdictions is on creating efficient land use and development control and assessment processes and they fail to adequately consider how the planning of settlements may create disaster resilient communities.

Cyclone Tracy has done little to influence the consideration of hazards in land use planning in Australia (Figure 11). However, the most enduring impact of Cyclone Tracy, has been improvements to the various jurisdictional building codes to require structures to withstand cyclonic wind forces especially within tropical cyclone prone areas in northern Australia. These codes are State/Territory based and have statutory force. The Building Codes that developed as a result of lessons learnt from Cyclone Tracy have been invaluable and have contributed to the resilience of settlements in north Queensland, as evidenced by the more limited damage to properties from Cyclone Larry in 2006 and Cyclone Yasi in 2011 than would have been the case had the building codes not been changed to reflect these requirements. However, building codes do not determine the location of development. This falls within the purview of the land use planning frameworks, as discussed earlier in this paper.
The two case studies clearly indicate that land use planning is not based upon creating hazard or disaster resilient communities. However, planning can reduce the physical vulnerability of settlements by identifying suitable low-hazard locations. The case studies show that despite their experiences with several cyclones and storm surges of various magnitudes, the communities persevere and grow. According to Lal and Deichmann [64], identifying and quantifying disaster risk is unlikely to reduce population growth even in the most hazard-prone cities, because locational decisions by corporations and people are storm-surge events and flooding pose the greatest threats to Machans Beach and these are directly related to the topography and geophysical aspects of the Barron delta-based community [18]. The lone access road to Machans Beach is impassable when high rainfall coincides with high tide events. In these instances, Machans Beach is inaccessible and, in turn, the residents are trapped. According to Nott [60], Machans Beach has experienced small-scale cyclone-generated storm-surge events from Tropical Cyclone Justin in 1997, Rona in 1999, Steve in 2000 and Yasi in 2011. Regular flooding occurs in the area due to its physical profile.

Storm-surge mapping indicates that the entire delta within Machans Beach would experience inundation at two metres or greater. Due to its topography and the three surrounding river networks, Machans Beach would be subject to minor and major storm-surge events. Access roads to Machans Beach would be impassable during high surge events [18]. According to the storm-surge models [18], the suburb would be one of the most seriously affected residential suburbs within Cairns and approximately 90 percent of dwellings would be flooded or isolated by water.

All development in Queensland is controlled through the Sustainable Planning Act 2009 (Qld) (hereafter referred to as SPA). The purpose of the SPA is to achieve ecological sustainability by:

(a) managing the process by which development takes place, including ensuring the process is accountable, effective and efficient and delivers sustainable outcomes; and

(b) managing the effects of development on the environment, including managing the use of premises; and

(c) continuing the coordination and integration of planning at the local, regional and State levels.

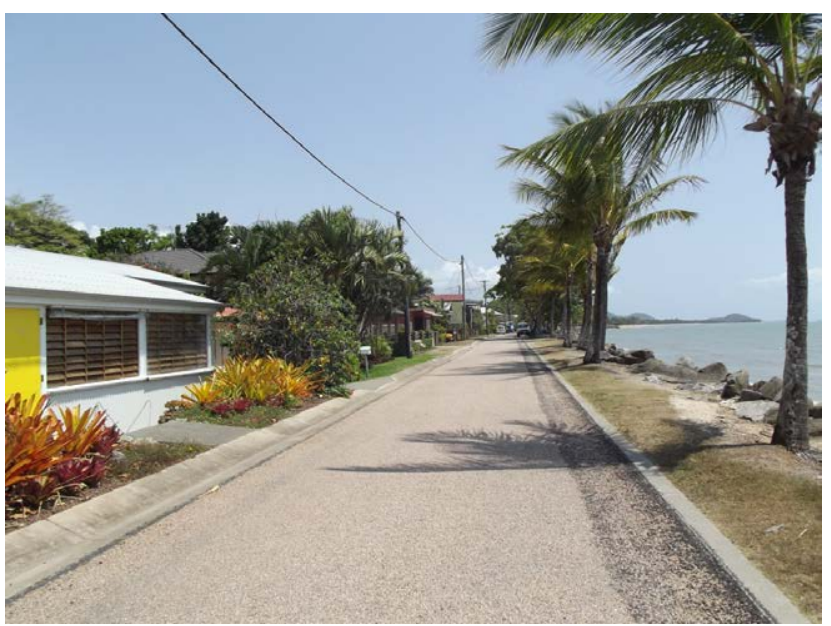

Figure 8: Machans Beach foreshore and rock wall in 2012 (photo Sharon Harwood). 
Citation: Harwood S, Carson D, Wensing E, Jackson L (2014) Natural Hazard Resilient Communities and Land Use Planning: The Limitations of Planning Governance in Tropical Australia. J Geogr Nat Disast 4: 130. doi:10.4172/2167-0587.1000130

Page 11 of 15

The purposes of the SPA are advanced through:

(a) ensuring decision-making processes are accountable, take account of short and long term environmental effects of development at various scales (including the effects of development on climate change), apply the precautionary principle, and provide equity between present and future generations;

(b) sustainable use of natural resources;

(c) reduction of environmental effects of development (climate change, urban congestion and human health);

(d) diversification of housing and the economy;

(e) infrastructural efficiency;

(f) enhancement of the amenities of the built environment; and

(g) opportunities for community involvement.

The SPA requires planning schemes to address the impacts of climate change, but not natural hazards (unless these hazards can be proven to be the result of climate change). There is no mandate to create hazard-resilient communities within the SPA, rather the focus is on procedural and environmental matters. The structure of the act requires all planning schemes within the state to comply with 'State Planning Policies' (SPP). The SPP most directly relevant to natural hazards is SPP1/03: Mitigating the Adverse Impacts of Flood, Bushfire and Landslide. However, this policy only requires the cumulative flood impacts of storm-tide inundation to be considered when determining the extent and severity of flood hazard. Storm surge is specifically triggered through an assessment process that incorporates the consideration of coastal hazards. The Queensland government is currently reviewing the coastal hazard policy and associated maps for the Cairns Region and has been for some time, therefore the impact of these maps on future development assessment processes is unclear.

Despite this policy review process, we can make conclusions about the planning system and the manner in which it treats storm surge through a review of a legal case heard in the local Planning and Environment Court. The following case (which describes a reconfiguration of a lot by creating two or more lots from the original one) highlights the scope of the influence that the legal system underpinning land use planning has (or does not have) on creating community resilience.

In 2007, two separate lot-reconfiguration applications (one subdividing a lot into two and the other subdividing one lot into three) were made to the Cairns Regional Council to intensify residential development on the beachfront of Machans Beach (Figure 9). Both applications were refused by the Cairns Regional Council on 11 November 2009. Both of the original lots contain prior development commitments to permit one house on each lot (with ancillary buildings). Council refused the applications to intensify on the basis of non-compliance with relevant planning-scheme requirements. Of the five grounds for refusal: one was for inadequate engineering mitigation, one was on the grounds of risk to natural hazard, and three on the grounds that the proposals impacted adversely on environmental values (erosion, riparian buffer and future waterway movement). Refusal was

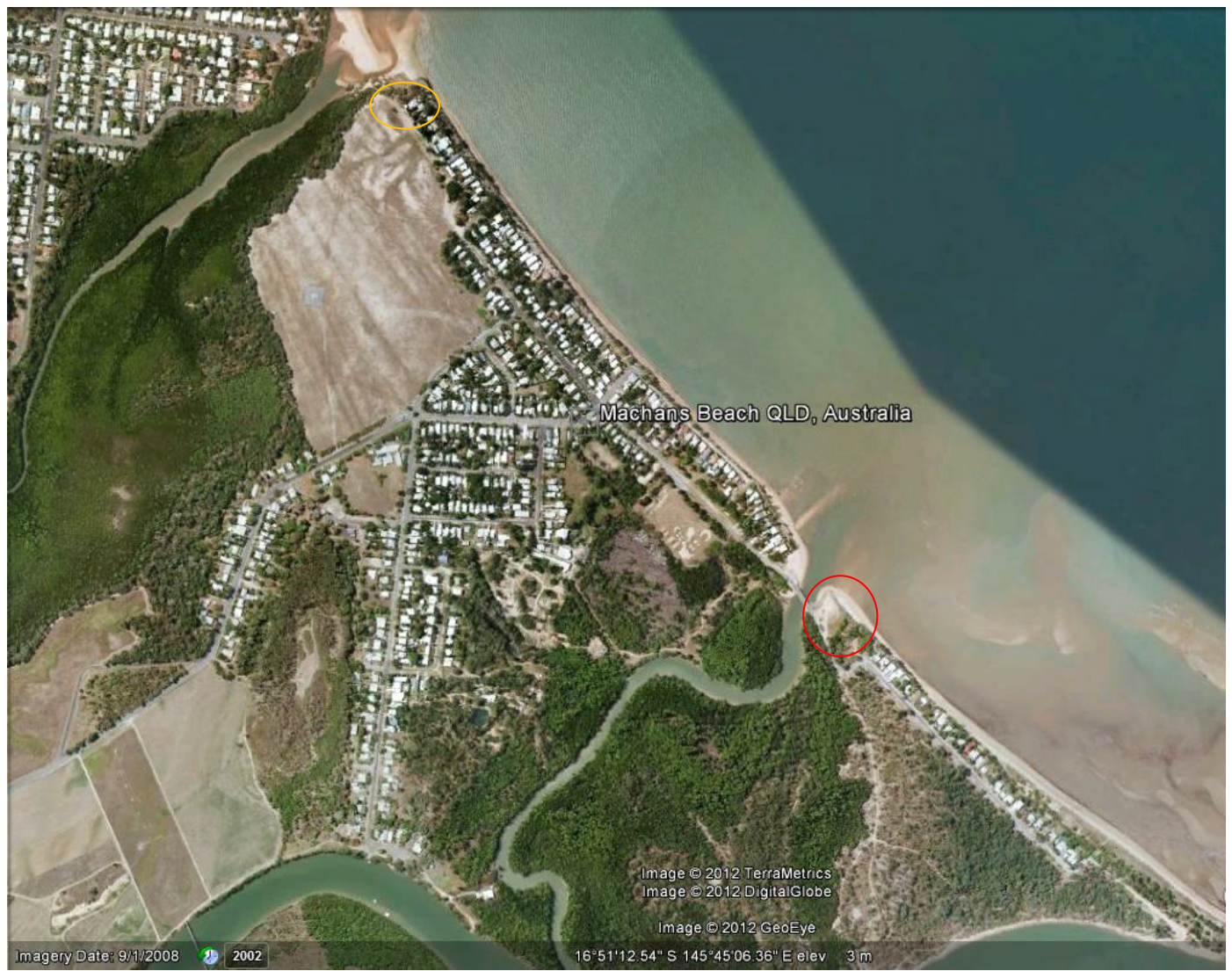

Figure 9: Google image of Machans Beach with approved reconfiguration lots. 


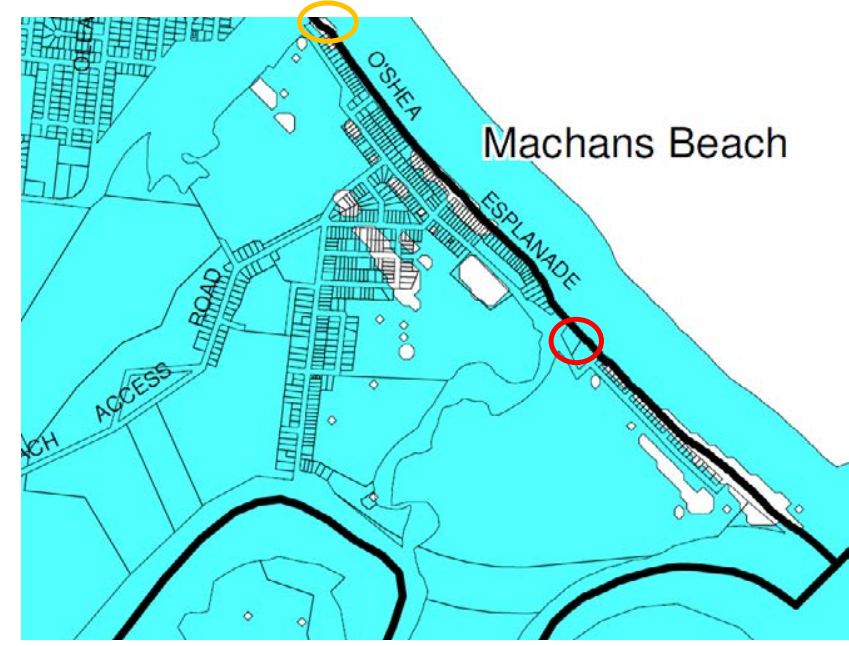

Figure 10: Cairns Regional Council 1:100 ARI defined flood event Machans Beach Queensland.

not based on the effect of the development upon community hazard resilience.

Subsequent to their refusals, both applications were appealed to the Planning and Environment Court by the proponent. The appeal focused on the integrity and location of the rock walls that separate the lots from the Coral Sea and the creeks that each abut. Expert evidence from engineers demonstrated that the existing rock walls had experienced previous cyclone and flooding events. The rock wall engineering certification was made in 2003 indicating that the rock wall was designed to withstand winds of $60 \mathrm{~m} / \mathrm{s}$ during a cyclone [61]. Both applications were approved by the Court subject to conditions. The approval was granted based on the engineering evidence provided. This evidence verified the ability of the rock walls to withstand the impacts of flooding and storm surge.

A 100-year ARI flood-inundation map has statutory force within the planning scheme (Figure 10). This map clearly indicates that the southern lot is likely to flood and the northern lot is not likely to flood.
A recent unpublished study [58] of the Machans Beach community regarding perceptions of storm surge indicates that minor storm surge events have been experienced at Machans Beach but have not been officially recorded. Moreover, there is no storm-surge mapping incorporated in the council's land use planning. Rather all data describe the inundation events as floods, which makes it difficult to separate storm-surge risk from river flood risk.

There are no provisions in any Queensland legislation that requires hazards to be noted on land titles and therefore no property disclosures apply for natural hazards. There is however, a range of information available to residents who live within Machans Beach on storm-surge hazard. The local government facilitates a Local Disaster Management Group (LDMG) that is chaired by its Mayor. The LDMG follows a Local Disaster Management Plan, which like its NT counterpart, has undertaken extensive risk assessments pursuant to the National Emergency Risk Assessment Guidelines [62] to identify the risk of all natural hazards in addition to developing a comprehensive strategy regarding the population characteristics including a vulnerable person's register to support emergency management procedures. In this particular instance the local government is responsible for both land use planning and supporting the LDMG and its initiatives. However, the data created and applied by the LDMG are not applied in the local planning scheme prepared by the local government. Moreover, in 2011 the LDMG released a series of storm-surge evacuation maps that clearly to function in their everyday lives as they did before they experienced a hazard event [7]. The hazards and emergency management literature maintains that communities could be more resilient to disasters through land use planning [4,8-12]. Stevens [2] goes so far as to claim that land use planning has adequately addressed the issue of hazard mitigation. However, planned development continues to occur in cyclone hazard-prone areas, and the planning literature has little to say about the role that land use planning has played or should play in creating hazard resilient communities in these areas.

The purpose of this article is to examine land use planning frameworks in tropical Australia to identify how the application of likely to favour agglomeration economies and the amenity value of large cities. Moreover, Lal and Deichmann [64] maintain that public policies aimed at slowing the growth of hazard-prone cities is unlikely

\begin{tabular}{|c|c|c|}
\hline Criteria & Darwin Northern Territory & Machans Beach Queensland \\
\hline Planning Legislation & Northern Territory of Australia Planning Act 2009 & Sustainable Planning Act 2009 \\
\hline Purpose of the Act & $\begin{array}{l}\text { To provide for appropriate and orderly planning and control of } \\
\text { the use and development of land, and for related purposes. }\end{array}$ & $\begin{array}{l}\text { Achieve ecological sustainability through managing the planning } \\
\text { process, managing the effects of development and through } \\
\text { government co-ordination. }\end{array}$ \\
\hline Objectives of the Act & $\begin{array}{l}\text { Objects of this Act are to plan for, and provide a framework } \\
\text { of controls for, the orderly use and development of land } \\
\text { through sustainable use of resources, strategic planning of } \\
\text { infrastructure, appropriate use of land, control of development } \\
\text { (natural environment, sustainable use of land and water } \\
\text { resources, minimising impacts of development upon amenity, } \\
\text { public consultation and fair and open decision making and } \\
\text { appeals processes. }\end{array}$ & $\begin{array}{l}\text { Advancing the purpose of the Act through decision making } \\
\text { processes, sustainable use of natural resources, lessening } \\
\text { environmental effects of development (climate change, urban } \\
\text { congestion and human health), housing and economic diversity, } \\
\text { infrastructure efficiency, amenity in the built environment and } \\
\text { opportunities for community involvement. }\end{array}$ \\
\hline State Planning Policy & $\begin{array}{l}\text { No provisions within the Northern Territory of Australia } \\
\text { Planning Act } 2009 \text { for state/territory planning policies. }\end{array}$ & $\begin{array}{l}\text { Flood mapping was included in the planning scheme pursuant to } \\
\text { State Planning Policy } 1 / 03 \text {. This policy is triggered through the } \\
\text { Sustainable Planning Act } 2009 \text {. }\end{array}$ \\
\hline Planning Scheme & $\begin{array}{l}\text { Considers storm surge. However despite these intensification } \\
\text { continues in declared primary and secondary storm surge } \\
\text { zones }\end{array}$ & $\begin{array}{l}\text { No storm surge maps, development is required to consider } \\
\text { flooding effects through overlay maps (pursuant to the State } \\
\text { Planning Policy 1/03). }\end{array}$ \\
\hline Property Disclosure & Nil & Nil \\
\hline Emergency Management Systems & $\begin{array}{l}\text { Systems in place to identify locations and respond to } \\
\text { disasters. No linkage between the data created and used by } \\
\text { Emergency Management and land use planning. }\end{array}$ & $\begin{array}{l}\text { Systems in place to identify locations and respond to disasters. } \\
\text { No linkage between the data created and used by Emergency } \\
\text { Management and land use planning. }\end{array}$ \\
\hline
\end{tabular}

Table 1: Summary of comparative legislative and planning policy frameworks. 


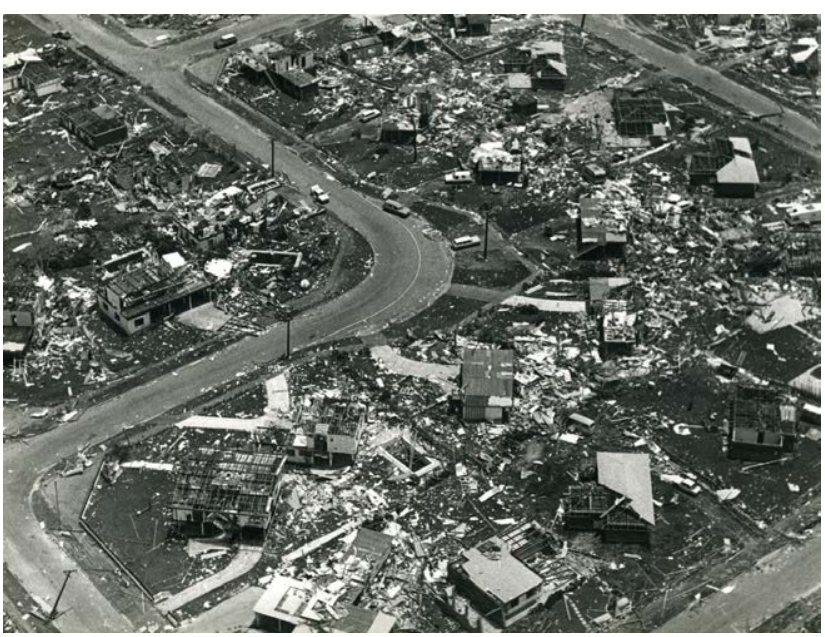

Figure 11: Cyclone Tracy damage in northern suburbs of Darwin.

to succeed. The challenge for creating disaster-resilient communities via the land use planning system, is finding a balance between facilitating growth (that appears to be inevitable) and mitigating risk.

The two case studies also show that the absence of a statutory requirement to properly consider the risk of loss of life, damage to property and destruction of vital infrastructure in their land use planning systems is a significant defect in the system. Both study sites have experienced the effects of tropical cyclones, yet the land use planning systems in both jurisdictions pay scant attention to the hazards arising from tropical cyclones, sea level rise and high tidal surges in their land use planning systems to delineate development away from these locations. There is an implicit disregard for the positive measures that could be incorporated into land use planning systems to deliver better outcomes in terms of hazard reduction and more disaster resilient communities. In turn, this places far greater reliance for response and recovery responsibilities upon the emergency services systems.

Furthermore, there is no mandatory requirement for the land use planning systems to use the data accumulated by the emergency management and disaster recovery systems to inform the development of strategic and statutory plans. There is no requirement to share this information across agencies and this inhibits the production of better knowledge, despite what the various jurisdictions have developed and committed to through the COAG processes discussed above. In particular, the suggestions documented in the NDRS with respect to reducing risks in the built environment [47], have not been taken up by the Queensland and Northern Territory Governments. What this analysis demonstrates is that the 'safe development paradox' is alive and well in tropical northern Australia.

The notion that hazard awareness and empirical evidence influence future development is, at best, tenuous. The case study of Machans Beach highlights how engineering can mitigate a hazard's impact upon environmental values and therefore can enable the intensification of development. At no point in this case, was the Planning and Environment Court concerned about the resilience of the residents who would eventually occupy the new subdivided lots. The Court's focus was on the structural integrity of the rock wall. Indeed, the Court could not hear matters relating to community resilience because these were not legally assessable indicators that could be considered by Council or the Court due to the absence of a legislative requirement for planning to create disaster resilient communities.

The land use planning system is an important aspect of hazard mitigation, but it can only be of use where the system is explicitly required to take the full range of hazards in an area into account. In another case heard in the Queensland Planning and Environment Court [63], a conservation group appealed a development decision on the basis that the development was within a storm-surge zone and therefore was inconsistent with contemporary legislative provisions. The court upheld the appeal and in its summary, maintained that planning is about balancing risk with economic development. Moreover, the local council defended its decision to approve the development because designing the whole site for potential events is impractical [62]. It, therefore, appears there is a perception that mitigating hazards in hazard-prone urban environments is counterproductive to achieving economic development. The seven previously mentioned land use planning priorities of the NDRS should be incorporated into the land use planning systems to ensure their robustness in reducing risk to loss of life, damage to property and destruction of vital infrastructure as well as in developing communities better disaster resilience built-in from the outset rather than as an afterthought.

The two case studies clearly indicate that land use planning is not based upon creating hazard resilient communities. However, planning can reduce the physical vulnerability of settlements by identifying suitable low-hazard locations. The case studies show that despite their experiences with several cyclones and storm surges of various magnitudes the communities persevere and grow. According to Lal and Deichmann [64], identifying and quantifying disaster risk is unlikely to reduce population growth even in the most hazard-prone cities because locational decisions by firms and people are likely to favour agglomeration economies and the amenity value of large cities. Moreover, Lal and Deichmann [64] maintain that public policies aimed at slowing the growth of hazard-prone cities is unlikely to succeed. The challenge for creating disaster-resilient communities via the land use planning system is finding a balance between facilitating growth (that appears to be inevitable) and mitigating risk.

\section{Conclusions}

This study clearly demonstrates that land use planning is not concerned with the hazard-resilience of communities. Land use planning frameworks are isolated and disconnected from the emergency management and disaster recovery systems, and there are no active policy linkages between the two systems, or not in so far as the impacts of tropical cyclones, sea level rise and high tidal surges are concerned, such that the two systems gain from each other's' knowledge and experience. Given the nature of the legal system that protects land use rights, it is highly unlikely that this situation will change in the immediate future. Creating hazard-resilient communities therefore remains the sole responsibility of emergency management and disaster recovery authorities as these organisations deal exclusively with a community's response in the event of a natural disaster, rather than also becoming the responsibility of the land use planning and development control agencies, state/territory and local.

The safe development paradox applies equally to tropical Australia as it does in the hurricane locations described by Burby [1] in the United

States of America. The mantra of the national government is to create hazard resilient communities, yet the very government institutions 
Citation: Harwood S, Carson D, Wensing E, Jackson L (2014) Natural Hazard Resilient Communities and Land Use Planning: The Limitations of Planning Governance in Tropical Australia. J Geogr Nat Disast 4: 130. doi:10.4172/2167-0587.1000130

Page 14 of 15

and associated systems that govern these systems are not structured or adequately tasked to achieve this goal. The hazards literature fails to understand the traditional purpose of land use planning and how communities protect their lifestyles and property rights through land use plans. If the goal of federal and state governments in Australia is to create hazard-resilient communities through land use planning, then a fundamental change to the way in which planning is conceptualised and practiced is urgently required. However, this fundamental change is not specific to just the planning fraternity, rather it also applies to all public institutions that affect disaster resilience, including planners, and emergency managers. Better mechanisms for sharing the data and knowledge accumulated by emergency management systems and for integrating that information into land use planning systems needs to happen as a matter of urgency. From the results of this analysis the most immediate actions necessary to create disaster resilient communities through land use planning systems in tropical Australia, include:

- Creating consistent methodologies and data frameworks to enable information-sharing between government agencies at all levels.

- Improving access to risk information data and developing more-effective collaboration to assess and monitor hazards and risks across jurisdictional boundaries for the benefit of the community.

- Improving access to data and tools to assess hazards and risks to enable communities to better understand the risks associated with being exposed to natural hazards.

\section{Acknowledgements}

The authors gratefully acknowledge the mapping contribution made by James Cook University Cartographer Ms Adella Edwards (Figure 5) and the Cairns Historical Society for the use of the 1966 photograph of Machans Beach (Figure 7), Pictures NT for Photo 1 (Figure 2) (PH:0026/0125 NT Department of Housing and Construction collection) and Figure $11(\mathrm{PH}: 0377 / 31844$ Coburg Collection).

\section{References}

1. Burby R (2006) Hurricane Katrina and the Paradoxes of Government Disaster Policy: Bringing About Wise Governmental Decisions for Hazardous Areas. The ANNALS of the American Academy of Political and Social Science 604: 171-191.

2. Stevens M (2010) Implementing Natural Hazard Mitigations Provisions: Exploring the Role that Individual Land Use Planners Can Play. Journal of Planning Literature 24: 362-371.

3. Blong R (2004) Issues in Risk Science: Natural Hazards Risk Assessment: An Australian Perspective. Benfield Hazard Research Centre, London.

4. West D (2011) North Queensland Brokers count the cost of Cyclone Yasi. National Insurance Brokers Association.

5. Coorey M (2011) Australia floods may cost coal business $\$ 8 \mathrm{bln}$. Sydney Morning Herald.

6. Commonwealth of Australia (2011) National Strategy for Disaster Resilience: Building our nation's resilience to disasters.

7. Harwood S, Carson D, Marino E, McTurk N (2011) Weather hazards, place and resilience in the remote Norths. In: Carson, Dean, Rasmussen, Rasmus Ole, Ensign, Prescott, Huskey, Lee, and Taylor, Andrew, (Edtn) Demography at the edge: remote human populations in developed nations. International Population Studies. Ashgate Publishing, Surrey, England

8. Li G (2009) (Mal) Adapting to tropical cyclone risk: the case of 'Tempestuous Tracy'. The Australian Journal of Emergency Management 24: 44-51.

9. March A, Hardy S (2007) A better future from imagining the worst: land use planning and training responses to natural disaster. The Australian Journal of Emergency Management 22: 17-22.

10. Yeo S, Grech P (2006) Flood prone caravan parks in NSW - is the system failing? The Australian Journal of Emergency Management 21: 12-21.

11. Burby R, Deyle R, Goldschalk D, Olshansky R (2000) Creating Hazard Resilient Communities Through Land Use Planning. Natural Hazards Review 1: 99-106.
12. Tobin G (1999) Sustainability and Community Resilience: the holy grail of hazards planning. Environmental Hazards 1: 13-25.

13. Northern Territory Counter Disaster Council (2012) The Northern Territory All Hazards Emergency Management Arrangements. Northern Territory Government, Australia.

14. Symes D, Akbar D, Gillen M Smith P (2009) Land Use Mitigation Strategies for Storm Surge Risk in South East Queensland. Australian Geographer 40: 121-136.

15. Yiftachel O (2006) Essay: Reengaging Planning Theory? Towards 'South Eastern' Perspectives. Planning Theory 5: 211-222.

16. Chadwick G (1971) A Systems View of Planning: Towards a Theory of the Urban and Regional Planning Process. Pergamon Press: Oxford, UK.

17. Hall P (1995) Cities of Tomorrow: An Intellectual History of Urban Planning and Design in the Twentieth Century. Blackwell: Oxford.

18. Granger K, Jones T, Leiba M, Scott G (1999) GeoScience Australia Commonwealth of Australia.

19. Wadley D, Smith $P$ (1998) If planning is about anything, What is it about? International Journal of Social Economics 25: 1005-1029.

20. Kanakubo T, Tanioka S (1980) Natural Hazard Mapping. Geojournal 4: 330340.

21. National Research Council (2006) Committee on Disaster research in the Social Sciences: Future Challenges and Opportunities. The National Academic Press: Washington DC

22. Cutter S, Emrich C (2006) Moral Hazard, Social Catastrophe: The Changing Face of Vulnerability along the Hurricane Coasts. American Academy of Political and Social Science 604: 102-112.

23. Klein R, Nicholls R, Thomalla F (2003) Resilience to natural hazards: how useful is this concept? Environmental Hazards 5: 35-45.

24. Maguire B, Cartwright S (2008) Assessing a community's capacity to manage change: A Resilience approach to social assessment. Bureau of Rural Sciences, Australian Government.

25. Bonanno G (2005) Resilience in the face of potential trauma. Current directions in Psychological Science 14: 135-138.

26. Keil A, Zeller M, Wida A, Sanim B, Birner R (2008) What determines farmers' resilience towards ENSO related drought? An empirical assessment in Central Sulawesi, Indonesia Climatic Change 86: 291-307.

27. Kelly G, Steed L (2004) Communities coping with change: A conceptual Model. Journal of Community Psychology 32: 201-216.

28. Murdoch V, Snyder C, Law H, Pamment P, Payne P (1985) Environmental Evaluations of a 'Hard Hat' Residential Area in Rural Australia. Journal of Community Psychology 13: 360-474.

29. Veiga M, Scoble M, McAllister M (2001) Mining with Communities. Natural Resources Forum 25: 191-202.

30. Nelson D, Adger N, Brown K (2007) Adaptation to Environmental Change: Contributions of a Resilience Framework. Annual Review of Environment and Resources 32: 395-419.

31. Tompkins E, Adger N (2003) Building Resilience to climate change through adaptive management of natural resources. Tyndall Working Paper 27, Tyndal Centre for Climate Change Research, University of East Anglia, Norwich, UK.

32. Cutter S, Boruff B, Shirley W (2003) Social Vulnerability to Environmenta hazards. Social Science Quarterly 84: 242-261.

33. Blaikie P, Cannon T, Davis I, Wisner B (1994) At Risk: Natural Hazards, People's Vulnerability, and Disasters. London: Routledge.

34. Phillips B, Metz W, Nieves L (2005) Disaster threat: Preparedness and potential response of the lowest income quartile. Environmental Hazards 6: 123-133.

35. Wu S, Yarnal B, Fisher, A (2002) Vulnerability of coastal communities to sea level rise: a case study of Cape May County, New Jersey, USA. Climate Research 22: 255-270.

36. King D, MacGregor C (2000) Using Social Indicators to Measure Socia Vulnerability to Natural Hazards. The Australian Journal of Emergency Management 3: 52-57. 
Citation: Harwood S, Carson D, Wensing E, Jackson L (2014) Natural Hazard Resilient Communities and Land Use Planning: The Limitations of Planning Governance in Tropical Australia. J Geogr Nat Disast 4: 130. doi:10.4172/2167-0587.1000130

Page 15 of 15

37. Adger W (2000) Social and ecological resilience: are they related? Progress in Human Geography 24: 347-64.

38. Folk C (2006) Resilience: the emergence of a perspective for social-ecological systems analyses. Global Environmental Change 16: 253-267.

39. Maguire B, Hagan P (2007) Disasters and communities: understanding social resilience. The Australian Journal of Emergency Management 22: 16-20.

40. Norris F, Stevens S, Pfefferbaum B, Wyche K, Pfefferbaum R (2008) Community Resilience as a Metaphor, Theory, Set of Capacities, and Strategy for Disaster Readiness. American Journal of Community Psychology 41:127-150

41. Carson D (2008) Demographic Changes in the Northern Territory following cyclone Tracy 1974/1975. Population Studies Research Brief.

42. Western J, Doube L (1978) Stress and Cyclone Tracy. In G. Pickup (Ed) Natural Hazards Management in North Australia. Proceedings of and papers arising out of a seminar held by the North Australia Research Unit Darwin, Australian National University.

43. Stretton A (1976) The Furious Days. The Relief of Darwin. Collins, Sydney, Australia.

44. King S (1979) More than meets the eye: Plans for land use change in Darwin after cyclone Tracey. In Aschman H, King S (Eds.) Two Northern Territory Urban Studies. Northern Australian Bulletin No. 5. North Australia Research Unit, Darwin, The Australian National University.

45. Council of Australian Governments (COAG) (2011a) COAG Meeting 13 February 2011, Communique. A New Strategic Direction for COAG and Increased Accountability.

46. Williams P, Maginn P (2012) Planning and Governance, Chapter 2 in Thompson, S. and Magin, P. Planning Australia. An Overview of Urban and Regional Planning, Second Edition, Cambridge University Press.

47. Council of Australian Governments (COAG) (2011b) National Strategy for Disaster Resilience. Building the resilience of our nation to disasters.

48. Council of Australian Governments (COAG) (2009) COAG Meeting 7 December 2009, Communique.

49. Council of Australian Governments (COAG) (2012) COAG Meeting 13 April 2012 Communique.
50. Standing Committee on Transport and Infrastructure (2009) Terms of Reference.

51. Standing Committee on Transport and Infrastructure (2012) Response to the COAG Reform Council's report: Review of capital city strategic planning systems.

52. Australian Government (2011) Our Cities, Our Future-A National Urban Policy for a productive, sustainable and liveable future. Department of Transport and Infrastructure.

53. Geva-May I (2002) Comparative Studies in Public Administration and Public Policy. Public Management Review. 4: 275-290.

54. Bureau of Meteorology (2011) http://www.bom.gov.au/cyclone/

55. Major Cities Unit (2012) State of Australian Cities 2012. Infrastructure Australia Canberra.

56. Northern Territory Planning Scheme (2007) Northern Territory Government, Australia.

57. Northern Territory All Hazards Emergency Arrangements (2012)

58. Australian Bureau of Statistics Quick Stats for Machans Beach (2011) 2011 Census QuickStats.

59. Jackson $L$ (2011) Examining the relationship between community resilience and disaster vulnerable settlements: the case of Machans Beach, Far North Queensland. James Cook University, Cairns Australia.

60. Nott J (2011) Professor (Physical Geography) James Cook University. Pers Comm. Regarding storm surges associated with tropical cyclones that have affected Machans Beach.

61. Roger McLeod vs Cairns Regional Council and Chief Executive Department of Transport and Main Roads. Queensland Planning and Environment Court Appeal 389 and 390 of 2009.

62. National Emergency Management Committee (2010) National Emergency Risk Assessment Guidelines, Tasmanian State Emergency Service, Hobart.

63. Mackay Conservation Group Inc. v Mackay City Council and East Point Mackay Pty Ltd (2005) Queensland Planning and Environment Court hearing 094.

64. Lal S, Deichmann U (2010) Density and Disasters: Economics of Urban Hazard Risk. Wider Angle.
Citation: Harwood S, Carson D, Wensing E, Jackson L (2014) Natural Hazard Resilient Communities and Land Use Planning: The Limitations of Planning Governance in Tropical Australia. J Geogr Nat Disast 4: 130. doi:10.4172/21670587.1000130
Submit your next manuscript and get advantages of OMICS Group submissions

Unique features:

- User friendly/feasible website-translation of your paper to 50 world's leading languages

Audio Version of published paper

Digital articles to share and explore

Special features:

400 Open Access Journals

30,000 editorial team

21 days rapid review process

Quality and quick editorial, review and publication processing

- Indexing at PubMed (partial), Scopus, EBSCO, Index Copernicus and Google Scholar etc

- Sharing Option: Social Networking Enabled

- Authors, Reviewers and Editors rewarded with online Scientific Credits

- Better discount for your subsequent articles

Submit your manuscript at: www.omicsonline.org/submission/ 